\title{
Trade Liberalization and Environmental Performance Index: Mediation Role of Climate Change Performance and Greenfield Investment
}

\author{
Ali Raza ${ }^{1,2}$, Hongguang Sui ${ }^{1, *}$, Kittisak Jermsittiparsert ${ }^{3}{ }^{\circledR}$, Wioletta Żukiewicz-Sobczak ${ }^{4}$ \\ and Pawel Sobczak $5, *$ (D) \\ 1 School of Economics, Shandong University, Jinan 250100, China; ali_raza@oyagsb.uum.edu.my \\ 2 Othman Yeop Abdullah Graduate School of Business, Universiti Utara Malaysia, Sintok 06010, Malaysia \\ 3 College of Innovative Business and Accountancy, Dhurakij Pundit University, Bangkok 10210, Thailand; \\ kittisak.jer@dpu.ac.th \\ 4 Department of Food and Nutrition, Calisia University, 62-800 Kalisz, Poland; \\ wiolazukiewiczsobczak@gmail.com \\ 5 Department of Food Engineering and Machines, University of Life Sciences in Lublin, 20-612 Lublin, Poland \\ * Correspondence: hongguang.sui@sdu.edu.cn (H.S.); pawel.sobczak@up.lublin.pl (P.S.)
}

check for updates

Citation: Raza, A.; Sui, H.; Jermsittiparsert, K.;

Żukiewicz-Sobczak, W.; Sobczak, P.

Trade Liberalization and

Environmental Performance Index:

Mediation Role of Climate Change Performance and Greenfield Investment. Sustainability 2021, 13, 9734. https://doi.org/10.3390/ su13179734

Academic Editor: Antonio Boggia

Received: 30 June 2021

Accepted: 24 August 2021

Published: 30 August 2021

Publisher's Note: MDPI stays neutral with regard to jurisdictional claims in published maps and institutional affiliations.

Copyright: (c) 2021 by the authors. Licensee MDPI, Basel, Switzerland. This article is an open access article distributed under the terms and conditions of the Creative Commons Attribution (CC BY) license (https:// creativecommons.org/licenses/by/ $4.0 /)$

\begin{abstract}
At present, concerns regarding climate change are common, especially in countries more vulnerable to environmental degradation. Greenhouse gases, including carbon emissions, are mainly considered to deteriorate the environment. Despite substantial agreement on many environmental issues, there are also important differences between regions and countries, and often, within nations. Accordingly, this study aims to examine the environmental performance of South and East Asian countries and its association with trade and other economic variables. Panel regression techniques and robust checks are used to examine the data, which covers 15 years from 2002 to 2016 . The findings suggest an extensive negative association between trade liberalization and the environmental performance of selected countries. It is also shown that climate change performance is an important channel for the overall environmental change. The results regarding heterogeneous differences affirm the concept of sustainability and the pollution halo hypothesis. However, it is suggested that each country should make an effort to improve its environmental performance along with economic development. The role of green innovation and renewable energy is very crucial in this regard. The outcomes of this study could be helpful for researchers and policymakers to form better policies regarding the environment and climate change.
\end{abstract}

Keywords: trade liberalization; environmental performance index; climate change performance; green-field investment; mediation effect; South and East Asian countries

\section{Introduction}

The world has experienced substantial economic growth over the last few decades because of trade and industrialization [1]. However, the environment and climate change have become a hot issue for debate globally due to the concerns for sustainable development [2,3]. Worldwide, the effects of climate change are not uniform. It is argued that developing countries are more likely to experience adverse environmental and climate change effects [4]. According to the World Economic Forum [5], Asia's GDP will overtake the rest of the world's GDP in 2020. The economic growth rate of developing Asia is higher than the world average. Such economic activities are increasing the risk of environmental deterioration and climate change in this region. It is reported that the emerging countries of Asia are more vulnerable at present in the context of environmental menaces [6,7]. Rohde and Muller [8] argued that the excessive flow of investment and speedy economic development had put Asian countries at the menace of environmental degradation and climate change. In 2018, the two major Asian economic giants, China and India, caused 27.8\% and 
$7.3 \%$ of the worlds' total carbon emissions [9]. The emerging markets of Southeast Asia are also experiencing similar environmental issues [10].

International trade is deliberated amongst various factors explaining the environmental issues [11-13]. The environment pollution and trade nexus was initially considered by economists such as Grossman and Krueger [14] and Shafik [15]. These researchers proposed a factual basis for the association between trade and the environment. The economic theory specifies that trade and foreign direct investment (FDI) lead to development and growth, especially in underdeveloped and emerging countries. Khan et al. [16] found that export of agricultural products improves the livelihood of local farmers. Trade liberalization and FDI across borders have formed several ecological challenges, locally and globally, through anthropogenic activities such as the rise in energy consumption, population growth, and economic growth and development [17]. Wacziarg and Welch [18] concluded that although trade liberalization leads to economic growth and creates employment opportunities, it worsens the ecological conditions of the host countries through the shift of contaminated and mass industrialization, higher energy consumption, and urbanization, which ultimately cause climate change.

In one aspect, trade liberalization augments the movement of goods and services and extends economic activities, while it puts grave effects on the environment. Liu et al. [12] demonstrated that international trade permits nations to transfer pollution-concentrated industries to other countries. In another aspect, international trade helps developing countries to increase their income level, which can be consumed to alleviate environmental pollution in the future [14]. Grether and DeMelo [19] stated that trade in developing countries led to either specialization or increased pollution-intensive production. Antweiler et al. [20] argued that the contradictory findings related to the emission-trade nexus arise from contradicting scale, technique, and composition effects. The study found that international trade creates relatively small changes in pollution concentrations when it alters the composition, and hence the pollution intensity, of national output.

Further, it is perceived that FDI amplifies the environmental degradation, as it increases the economic activities in the host countries. However, on the other side, FDI may introduce cleaner technologies and better management practices to improve the environmental quality of host countries. In this regard, by separating the effect of green-field FDI and mergers and acquisitions (M\&A) on the environment, Ashraf et al. [21] found that green-field FDI increases pollution, supporting the pollution haven hypothesis, while M\&A decrease pollution, in line with the halo effect hypothesis. Greenfield FDI refers to investment which involves building everything the business needs from the ground. In addition, global climate change has already had observable effects on the environment. Climate change may aggravate erosion, decline in organic matter, salinization, soil biodiversity loss, landslides, desertification, and flooding [22]. The effect of climate change on soil carbon storage can be related to changing atmospheric $\mathrm{CO}_{2}$ concentrations, increased temperatures, and changing precipitation patterns.

Previously, different proxies of the environment have been used by researchers, such as sulfur dioxide $\left(\mathrm{SO}_{2}\right)$ emissions [23], nitrous oxide $\left(\mathrm{N}_{2} \mathrm{O}\right)$ emissions [24,25], and particulate matter (PM 2.5) [26]. However, the most relevant and frequently used indicator of the environment is carbon dioxide $\left(\mathrm{CO}_{2}\right)$ emissions [27-30]. Each proxy provides a record of environmental change, but the process of spatially combining these indicators into a large scale requires careful statistical evaluation. In this respect, the Environmental Performance Index (EPI) developed by Yale University is regarded as an all-inclusive proxy to examine the country's environmental conditions [31,32]. Ozturk et al. [33] also argued that $\mathrm{CO}_{2}$ emissions only cover a small part of the total environmental pollution. The recently revised EPI of 2020 comprises 32 performance indicators across 11 issue categories. It ranks countries under two domains, environmental health and ecosystem vitality, which demonstrate the environmental pollution impacts on human health and also the effects that ensue on the ecosystem through environmental pollution. The Environmental Health Index 
(HLT) measures the quality of air, water, and exposure to heavy metals. The Ecosystem Vitality Index (ECO) considers issues such as climate change and biodiversity.

As discussed, EPI is a more suitable and wide-ranging indicator to examine environmental performance and offers concrete guidelines for nations that seek to move towards a sustainable future. The main research question of this study is how trade liberalization affects the environmental performance (EPI) of the selected South and East Asian countries. The study is expected to propose more robust policy implications concerning the trade and environment nexus. Specifically, this study contributes to the current literature in the following three ways. First, in the prevailing literature, the predominant measures used to examine the environment are $\mathrm{CO}_{2}$ and greenhouse gas emissions, with a few exceptions. Unlike most previous studies, this study used EPI (2020) for the comprehensive analysis of environmental performance with regards to trade liberalization. Second, the role of climate change performance and green-field investment is also explored using the mediation method concerning the trade-environment nexus. Third, as we are using panel data, heterogeneous differences are also explored based on per capita income, manufacturing GDP, and population size. Such a broad analysis can help refine policy choices, understand the determinants of environment, and maximize the relevant policy implications based on the estimated results.

Section 2, which follows, presents the literature review. Section 3 explains the data, sources, and empirical models employed in the study. In Section 4, results based on empirical estimations are discussed. Sections 5 and 6 discuss the mediation and heterogeneous differences, respectively. Lastly, the conclusion and policy recommendations are given in Section 7.

\section{Literature Review}

In the prevailing literature, numerous studies have explored the association between trade and the environment in various countries. The role of trade liberalization in encouraging or discouraging environmental deterioration has been a contentious issue in the literature. It has been evident that the association between trade liberalization and the environment is not uni-directional [20,34-36]. Udeagha and Ngepah [37] examined the association between trade and environmental quality in South Africa. The findings show that the country has a comparative advantage in exports of products that necessitate energy that is met by consuming fossil fuels, which eventually deteriorates the environment significantly. By utilizing the instrumental variable quantile approach of panel data, Kim et al. [28] studied the trade and environment nexus for northern and southern regions of the US. The study revealed that international trade with the North increases $\mathrm{CO}_{2}$ emissions, whereas trade with the South mitigates $\mathrm{CO}_{2}$ emissions, with a relatively larger effect for less polluted host countries. The findings suggest that, in terms of $\mathrm{CO}_{2}$ emissions, trade benefits the advanced countries but could hurt the developing countries when trade with high-income trading partners occurs. Dogan and Seker [27] explored the effect of real income, energy consumption, renewable energy, financial development, and trade on the environment by using the fully modified ordinary least squares (FMOLS) and dynamic ordinary least squares (DOLS) approaches; the outcomes found a positive association between energy consumption and $\mathrm{CO}_{2}$ emissions, while a negative association was found for renewable energy, economic growth, energy use, and trade.

Omri et al. [38] scrutinized the association between trade, economic growth, and financial development on $\mathrm{CO}_{2}$ emissions by employing simultaneous-equation models for 12 MENA panels over the period 1990-2011. The outcomes showed a two-way directional causality between economic growth and $\mathrm{CO}_{2}$ emissions, and a one-way directional causality was found between trade and $\mathrm{CO}_{2}$ emissions. Aller et al. [39] explored the role of world trade in environmental sustainability by pinpointing the important countries engaged in social networking. The findings showed that trade networks adversely affect developed countries' environments while regenerating developing countries' environments. The study argued that stronger environmental policy in developing countries for multinationals may 
help to alleviate environmental degradation. Mahrinasari et al. [40] considered the panel of ASEAN countries to study the trade and environment nexus using DOLS and FMOLS. The outcomes suggested that trade liberalization significantly and positively influence carbon emissions. Ahmed et al. [41] concluded that although trade liberalization spurs economic growth, it does so at the cost of environmental degradation. Several other prior studies also report similar findings [42-49].

In contrast to some of the studies discussed above, it has been argued that the effect of trade liberalization is not as detrimental for the environment as is considered [50-58]. Zhang et al. [59] argued that international trade generally affects industrial output composition, leading countries to concentrate on those productions where their relative costs are almost lower. If trade leads a country to concentrate on pollution-intensive production, then the composition effect increases pollution and causes climate change. Alternatively, if trade leads a country to focus relatively on clean goods production, this composition effect sinks pollution and recovers the quality of the environment. The enormous economic growth due to merchandise exports has been evident in the developing countries of Asia. Li et al. [60] argued that if economic gains stress protection of the environment or deliver funds to invest in environmental protection strategies, alterations in production techniques may be helpful, that is, the technique effect may lead to less pollution by utilizing income generated from trade. The evidence of effects of international trade on environmental performance in various countries differs by income, or maybe due to differences in policies, economic structure, economic openness level, and specific variations of the country [61-63].

Adeel et al. [32] examined the influence of foreign direct investment, energy consumption, economic growth, and urbanization on EPI. The findings showed that foreign investment has a significant adverse effect on environmental performance, but economic growth is positively associated with EPI. Ashraf et al. [21] found that green-field investment flowing into poorer countries worsens the environment, while M\&A flowing to industrialized economies reduce pollution. Liu et al. [64] argued that FDI had distinct effects on different environmental pollutants. The study finds that FDI reduced waste soot and dust but increased wastewater and sulfur dioxide. Bildirici and Gokmenoglub [65] found that changes in $\mathrm{CO}_{2}$ emissions are linked with terrorism, FDI, and growth in the long run. However, Demena and Afesorgborb [66] argued that the underlying effect of FDI on emissions is close to zero. The results remain robust for different groups of countries and for different pollutants.

By reviewing the prevailing literature, it can be observed that there are not many studies available that analyze the relationship between trade and a comprehensive proxy of the environment, and the evidence is mixed [67]. Therefore, to enrich the limited literature on this topic, the current research examines the effects of trade on the environment by measuring EPI. This research is also significant in that there was no prior research that used mediation analysis to investigate the potential mechanism between trade liberalization, climate change, green-field investment, and environmental performance. Further, difference analysis based on per capita income, manufacturing economy, and population is incorporated to explore study sample differences. It is believed that this research could probably help policymakers form their strategies based on the results gained through systematic empirical analysis.

\section{Materials and Methods}

The dataset related to twelve South and East Asian countries was collected for empirical investigation as these countries are predominantly considered emerging economies. The countries included in the analysis are Bangladesh, India, Pakistan, Sri Lanka, China, South Korea, Indonesia, Malaysia, Singapore, Thailand, Vietnam, and the Philippines. The dataset is diverse as it covers both upper and lower-middle-income countries. The study focused on these countries due to the greater environmental and climate change concerns in these regions. Based on data availability, the study duration consists of 15 years, from 2002 to 2016. All the data is collected from secondary sources. Specifically, the GDP, 
urbanization, and FDI data was collected from the World Development Indicators (WDI). Trade and green-field investment data was collected from the United Nations Conference on Trade and Development (UNCTAD). Energy consumption data was collected from British Petroleum (BP). EPI and climate change indicator data was obtained from NASA's open data portal.

The main variable, environmental performance $(E P I)$ is measured according to the latest environmental performance index of 2020. The EPI scores of each country are calculated from 2002 to 2016 by weighing each indicator percentage suggested in EPI 2020. The variable Climate is the climate change performance score of the selected countries. It is also measured according to the weightage given in the EPI report of 2020. The variable lnGFI is the natural log of green-field investment value in USD at the destination. The primary explanatory variable Trade is measured as the ratio of exports and imports value in USD over total GDP of the country. The study also included $\ln G D P, \operatorname{lnFDI}$, $\ln E n e r g y$, and InUrban as control variables based on the prior empirical literature. The variables $\ln G D P$ and $\ln F D I$ are measured as the logged value of the country's total gross domestic product and foreign direct investment in USD. The variable InEnergy is the log of total energy consumption, and lnUrban is the log of the urban population of each country. The variables are used in log form to address nonlinear association concerns and interpret results as elasticities.

Further, the dummy variables included in the analysis are measured as PCI_dummy = 1 if per capita income $>10,000$ in USD, otherwise it is 0; the variable Mfg.GDP_dummy = 1 if manufacturing GDP of the country $>20 \%$ of total GDP, otherwise it is 0 ; the variable Population_dummy $=1$ if the country's population size $>100$ million, otherwise it is 0 .

\section{Empirical Estimations}

The empirical specification used in this paper derives from the standard trade and environment framework. The study equation with control variables is constructed in the following panel regression model:

$$
E P I_{i t}=\beta_{0}+\beta_{1} \text { Trade }_{i t}+\beta_{2} \ln G D P_{i t}+\beta_{3} \ln F D I_{i t}+\beta_{4} \ln E n e r g y_{i t}+\beta_{5} \ln U r b a n_{i t}+\varepsilon_{i t}
$$

where $i$ denotes the number of countries included in the sample, and $t$ indicates the time; $\beta_{1}, \beta_{2}, \beta_{3}, \beta_{4}, \beta_{5}$ are the coefficients parameters, whereas $\varepsilon_{i t}$ is the error term.

The study further employed mediation analysis by including Climate and InGFI variables. Firstly, it is argued that climate change performance (Climate) has a considerable role in the overall environmental performance of the country. Therefore, to examine this affect empirically, the following equations have been derived by using the step-by-step mediation method of Baron and Kenny.

$$
\text { Climate }_{i t}=c_{0}+\delta_{1} \text { Trade }_{i t}+\beta_{1} \ln G D P_{i t}+\beta_{2} \ln F D I_{i t}+\beta_{3} \text { Energy }_{i t}+\beta_{4} \ln U r b a n_{i t}+\varepsilon_{i t}
$$

$$
E P I_{i t}=c_{1}+\varphi_{1} \text { Climate }_{i t}+\varphi_{2} \text { Trade }_{i t}+\beta_{1} \ln G D P_{i t}+\beta_{2} \operatorname{lnFDI}_{i t}+\beta_{3} \ln \text { Energy }_{i t}+\beta_{4} \ln \text { Urban }_{i t}+\varepsilon_{i t}
$$

Secondly mediator $\ln$ GFI included in the model as it is perceived that green-field investment inflows deteriorate environmental quality more than other type of investment [32]. The mediation equations are as follows:

$$
\begin{array}{r}
\ln G F I_{i t}=c_{0}+\delta_{1} \text { Trade }_{i t}+\beta_{1} \ln G D P_{i t}+\beta_{2} \ln F D I_{i t}+\beta_{3} \ln E n e r g y_{i t}+\beta_{4} \ln U r b a n_{i t}+\varepsilon_{i t} \\
E P I_{i t}=c_{1}+\varphi_{1} \ln G F I_{i t}+\varphi_{2} \text { Trade }_{i t}+\beta_{1} \ln G D P_{i t}+\beta_{2} \ln F D I_{i t}+\beta_{3} \ln \text { Energy }_{i t}+\beta_{4} \ln U r b a n_{i t}+\varepsilon_{i t}
\end{array}
$$

where $c_{0}$ is the constant, $\delta_{1}$ is the parameter for trade liberalization and $\beta_{1}$ to $\beta_{4}$ are the parameters for the control variables in Equations (2) and (4). For step 2, in Equations (3) and (5), $\varphi_{1}$ and $\varphi_{2}$ are the parameters for mediating variables and trade liberalization, otherwise it is the same. 
Additional to the above estimations, the heterogeneous differences among sampled countries are also explored. The dummy variables are used to group the sample countries based on per capita income, manufacturing GDP, and population size. The equations are as follows:

$$
\begin{aligned}
& E P I_{i t}=\beta_{0}+\beta_{1} \operatorname{Trade}_{i t}+\beta_{2} P C I_{-} \text {dummy }_{i t}+\beta_{3} \ln G D P_{i t}+\beta_{4} \operatorname{lnFDI} I_{i t}+\beta_{5} \ln E_{n e r g y}+\beta_{6} \ln \text { Urban }_{i t}+\varepsilon_{i t} \\
& E P I_{i t}=\beta_{0}+\beta_{1} \text { Trade }_{i t}+\beta_{2} \ln G D P_{i t}+\beta_{3} M f g . G D P \_d u m m y_{i t}+\beta_{4} \ln F D I_{i t}+\beta_{5} \ln E_{n e r g y}+\beta_{6} \ln U r b a n_{i t}+\varepsilon_{i t} \\
& E P I_{i t}=\beta_{0}+\beta_{1} \text { Trade }_{i t}+\beta_{2} \ln G D P_{i t}+\beta_{3} \ln F D I_{i t}+\beta_{4} \ln \text { Energy }_{i t}+\beta_{5} \ln U r b a n_{i t}+\beta_{6} \text { Population_dummy }_{i t}+\varepsilon_{i t}
\end{aligned}
$$

The coefficient parameters describe the relationship between dummy variables and the environmental performance of sample countries.

\section{Results}

\subsection{Descriptive Statistics}

Table 1 show that the mean score of EPI for the study sample is 55.92, with a minimum score of 25.03 and a maximum of 65.21 . The mean score of climate change performance Climate is 13.42 , with a minimum score of 6 and a maximum of 15.60 . The sample mean of $\ln G F I$ is 3.94 , and the minimum and maximum values are 1.72 and 5.11 , respectively. The variable Trade has a mean percentage of 88.78 with a minimum of 20.89 and a maximum of 345.36 percent. The summary statistics of other control variables show the normal trend.

Table 1. Descriptive statistics.

\begin{tabular}{cccccc}
\hline Variables & Obs. & Mean & Std. Dev. & Min. & Max. \\
\hline EPI & 180 & 55.920 & 12.299 & 25.034 & 65.210 \\
Climate & 180 & 13.421 & 2.952 & 6.008 & 15.601 \\
InGFI & 180 & 3.941 & 0.602 & 1.723 & 5.110 \\
Trade & 180 & 88.781 & 73.128 & 20.886 & 345.355 \\
InGDP & 180 & 11.469 & 0.583 & 10.218 & 13.047 \\
InFDI & 179 & 3.759 & 0.692 & 2.164 & 5.132 \\
lnEnergy & 180 & 0.555 & 0.656 & 0.747 & 2.104 \\
InUrban & 180 & 7.623 & 0.629 & 6.544 & 8.893 \\
\hline
\end{tabular}

\subsection{Main Regression Results}

To estimate the relationship between EPI and other independent variables, the study employed panel regression analysis techniques. Due to unobserved heterogeneity, the results could be biased in OLS, so to get unbiased results, random and fixed effects models are employed. The results are shown in Table 2 below. The findings illustrate that trade liberalization is strongly associated with the EPI at a $1 \%$ significance level. The result specifies that a 1 percent increase in Trade lessens the EPI score by 0.093 in random effect estimation and 0.132 in fixed effect. The direction of the relationship is negative, which supports the idea that countries with more international trade are more vulnerable to deteriorating environment quality and aggravating climate change. It suggests that trade in emerging countries mostly comprises energy-intensive products, which necessitates energy consumption and eventually leads to a deteriorating ecosystem. Moreover, the fossil fuels share in the total energy mix in developing countries is also getting higher, lessening the developing countries' environmental performance. According to the World Bank [68], since 1990 to 2014 energy consumption has risen to $1922.5 \mathrm{~kg}$ of oil equivalent per capita from $1662.93 \mathrm{~kg}$ of oil equivalent per capita globally. The increased use of energy prompts numerous environmental issues [69]. Compared to the 1970 s, total $\mathrm{CO}_{2}$ emissions in 2018 rose to $33,890.80$ million tons [9]. 
Table 2. Main regression results.

\begin{tabular}{|c|c|c|c|}
\hline Variables & (1) & (2) & (3) \\
\hline & OLS & Random Effect & Fixed Effect \\
\hline Trade & $\begin{array}{l}0.032 * \\
(0.019)\end{array}$ & $\begin{array}{c}-0.093^{* * *} \\
(0.023)\end{array}$ & $\begin{array}{c}-0.132 * * * \\
(0.024)\end{array}$ \\
\hline $\ln G D P$ & $\begin{array}{c}34.457 * * * \\
(4.219)\end{array}$ & $\begin{array}{c}37.702 * * * \\
(3.911)\end{array}$ & $\begin{array}{c}26.211^{* * * *} \\
(5.822)\end{array}$ \\
\hline $\operatorname{lnFDI}$ & $\begin{array}{c}0.199 \\
(2.317)\end{array}$ & $\begin{array}{l}-2.091 \\
(1.807)\end{array}$ & $\begin{array}{l}-2.781 \\
(1.758)\end{array}$ \\
\hline InEnergy & $\begin{array}{c}-17.152 * * * \\
(4.335)\end{array}$ & $\begin{array}{l}-0.417 \\
(7.297)\end{array}$ & $\begin{array}{c}8.953 \\
(13.539)\end{array}$ \\
\hline lnUrban & $\begin{array}{c}-15.761 * * * \\
(2.853)\end{array}$ & $\begin{array}{c}-37.084^{* * * *} \\
(6.387)\end{array}$ & $\begin{array}{c}3.333 \\
(23.709)\end{array}$ \\
\hline Constant & $\begin{array}{c}-213.232^{* * *} \\
(55.346)\end{array}$ & $\begin{array}{l}-77.473 \\
(69.393)\end{array}$ & $\begin{array}{l}-252.816 \\
(162.168)\end{array}$ \\
\hline Observations & 179 & 179 & 179 \\
\hline$R$-squared & 0.587 & 0.636 & 0.656 \\
\hline $\begin{array}{l}\text { Hausman test: } \\
\text { Chi-square (5) } \\
\text { Prob > chi-square }\end{array}$ & $\begin{array}{c}35.88 \\
0.00\end{array}$ & & \\
\hline
\end{tabular}

Further, the environmental deterioration in South and East Asian countries reflects the fact that these economies have less-regulated laws for the environment. Baek et al. [61] and Bernard and Mandal [70], in their study models, found that trade has no substantial influence on the environment, though it intensifies carbon emissions to some extent. The results suggest that international trade also helps to shift cleaner production technologies to developing countries, which enhances environmental quality. The prior studies of Jamel and Maktouf [71] and Shahbaz et al. [34] supported this study's findings, stating that trade causes poor environmental conditions due to unsustainable use of resources. The findings correspond well with the recent study of Essandoh et al. [72], who also proved that trade decreased $\mathrm{CO}_{2}$ emissions in developed countries, but international transactions increased $\mathrm{CO}_{2}$ emissions in developing regions. Other studies that supported our results include Adeel et al. [32], Kohler [73], Raza and Shah [74], Solarin and Al-Mulali [75], FernándezAmador et al. [76], and Balin et al. [77]. Ozturk and Acaravci [78] also explored the associations among economic growth, energy, financial growth, and trade openness. They found that energy is increasingly consumed as a result of economic development and trade. In contrast, some studies have argued that trade liberalization benefits climate change and improve the environmental quality, as openness to trade in developing countries has led to specialization $[50-54,79,80]$.

The other variable $\ln G D P$ was found to influence the environmental performance of the country strongly. It is inferred that GDP increases the environmental performance as the countries become more able to adapt to environmentally friendly technologies. The result suggests that South and East Asian countries, after improving their industrial structure, employment, and income, are inclined to opt for environmentally friendly technologies to mitigate pollution (halo effect). They have maximized their reliance on renewable sources of energy to meet the requirement of economic activities. More economic growth leads to more income that leads to more environmentally friendly sources of energy for goods production. The results are consistent with the findings of Aziz et al. [81], Si et al. [82,83], and Koondhar et al. [84]. In the case of BRICS and the MINT panel, Aziz et al. [85,86] revealed that countries, after attaining a certain level of income, are inclined to regenerate the environment.

Unlike the previous literature, the FDI and Energy results in the current study are not statistically significant in the main regression models. This result also shows that trade liberalization is the most adverse determinant of low environmental performance. 
However, previous studies using individual proxies of the environment show the strong association between FDI and energy consumption. Xie et al. [87] stated that FDI directly upsurges $\mathrm{CO}_{2}$ emissions, even though the spillover effect through economic growth shows a negative association. Likewise, Shahbaz et al. [88] also found that FDI deteriorates the environment in various countries based on income level. In low-income countries such as Pakistan, Khan et al. [89] found that FDI negatively influences the environment in the long run, while the results were insignificant in the short run. Tamazian and Rao [90], Hossain [91], and Omri [92] show that energy consumption is a leading factor for emissions. Further, urbanization negatively affects environmental performance in the random effects model but not in fixed effects.

Overall, the model is a good fit and has $R^{2}$ value of 0.63 in the case of random effect and 0.65 in fixed effect. The study also employed the Hausman's specification test to identify the more appropriate model. The significant $p$-value (35.88) of chi-sq suggests that the fixed effect model is more appropriate, as shown in Table 2. There is not much difference in the values of $R^{2}$ in both the random effect and fixed-effect models. Overall, the results are reliable in both models and signify that trade liberalization has an unfavorable impact on environmental performance. Still, income growth in these countries may help reduce this effect.

\subsection{Robust Test}

To get the robust standard errors and determine the accuracy of the estimations, the study employed the VCE robust test and EPI lagged model [93]. Table 3 shows that the findings are consistent with the main random and fixed effects models and are approximately parallel to the previous findings attained in Table 2. Trade liberalization adversely influences the environmental performance of the selected Asian panel. The results are substantially affirmed by robust standard errors as well as with lagged regression model.

Table 3. Regression results with robust standard errors.

\begin{tabular}{|c|c|c|c|c|}
\hline & (1) & (2) & (3) & (4) \\
\hline \multirow{2}{*}{ Variables } & \multicolumn{2}{|c|}{ VCE_Robust } & \multicolumn{2}{|c|}{ VCE_Robust with Lagged EPI } \\
\hline & Random Effect & Fixed Effect & Random Effect & Fixed Effect \\
\hline Trade & $\begin{array}{c}-0.093 * \\
(0.053)\end{array}$ & $\begin{array}{c}-0.132 * * * \\
(0.032)\end{array}$ & $\begin{array}{c}-0.131 * * * \\
(0.044)\end{array}$ & $\begin{array}{c}-0.218^{* * *} \\
(0.017)\end{array}$ \\
\hline $\ln G D P$ & $\begin{array}{c}37.702^{* * * *} \\
(6.437)\end{array}$ & $\begin{array}{c}26.211^{* * * *} \\
(8.217)\end{array}$ & $\begin{array}{c}19.602^{* * *} \\
(7.127)\end{array}$ & $\begin{array}{c}0.655 \\
(6.160)\end{array}$ \\
\hline $\ln F D I$ & $\begin{array}{l}-2.091 \\
(2.286)\end{array}$ & $\begin{array}{l}-2.781 \\
(2.041)\end{array}$ & $\begin{array}{l}-1.869 \\
(2.376)\end{array}$ & $\begin{array}{l}-3.333 \\
(2.020)\end{array}$ \\
\hline InEnergy & $\begin{array}{c}-0.418 \\
(11.712)\end{array}$ & $\begin{array}{c}8.954 \\
(14.997)\end{array}$ & $\begin{array}{c}15.149 \\
(11.973)\end{array}$ & $\begin{array}{c}19.847 \\
(15.771)\end{array}$ \\
\hline InUrban & $\begin{array}{c}-37.084 * * * \\
(12.075)\end{array}$ & $\begin{array}{c}3.333 \\
(36.467)\end{array}$ & $\begin{array}{c}-40.704^{* * *} \\
(11.591)\end{array}$ & $\begin{array}{l}45.701^{*} \\
(23.191)\end{array}$ \\
\hline Constant & $\begin{array}{c}-77.473 \\
(116.969)\end{array}$ & $\begin{array}{l}-252.816 \\
(205.212)\end{array}$ & $\begin{array}{c}151.516 \\
(120.614)\end{array}$ & $\begin{array}{l}-278.893 \\
(171.723)\end{array}$ \\
\hline Observations & 179 & 179 & 178 & 178 \\
\hline$R$-squared & 0.636 & 0.656 & 0.358 & 0.421 \\
\hline
\end{tabular}

Note: Standard errors are in parentheses; ${ }^{* * *},{ }^{* *},{ }^{*}$ show statistical significance at the $0.01,0.05$, and 0.1 level, respectively.

\section{Mediation Analyses}

\subsection{Climate Change}

For mediation analysis, primarily, climate change performance is used as a mediator to cover considerable weightage in the total environmental performance index. Using a step-by-step approach, the Panel A model in Table 4 shows a huge impact of trade liberalization on climate change performance, as the $1 \%$ change in Trade decreases the Climate by 0.022 and 0.032 in the case of both random effect and fixed effect. As shown in the Panel B model, climate change performance significantly and positively improves environmental 
performance. Therefore, the relationship between trade and environmental performance is found to be partially mediated by climate change score. Many earlier studies also proved that trade exacerbates the ecosystem and leads to climate change $[28,38,40]$. Prior studies of Apergis and Payne [43], Acaravci and Ozturk [44], Nasir and Ur-Rehman [45], Jayanthakumaran et al. [46], Shahbaz et al. [47], Kasman and Duman [48], and Dogan and Turkekul [49] also affirm similar results and conclude that although trade liberalization spurs economic growth, it does so at the cost of environmental deterioration and climate change.

Table 4. Regression results with Mediator_Climate.

\begin{tabular}{|c|c|c|c|c|}
\hline & (1) & (2) & (3) & (4) \\
\hline \multirow{2}{*}{ Variables } & \multicolumn{2}{|c|}{ Panel_A } & \multicolumn{2}{|c|}{ Panel_B } \\
\hline & Random Effect & Fixed Effect & Random Effect & Fixed Effect \\
\hline Climate & \multicolumn{2}{|c|}{-} & $\begin{array}{c}132.697^{* * * *} \\
(2.366)\end{array}$ & $\begin{array}{c}132.258^{* * *} \\
(2.664)\end{array}$ \\
\hline Trade & $\begin{array}{c}-0.022 * * * \\
(0.006)\end{array}$ & $\begin{array}{c}-0.032^{* * *} \\
(0.006)\end{array}$ & $\begin{array}{c}-0.022 * * * \\
(0.005)\end{array}$ & $\begin{array}{c}-0.042^{* * *} \\
(0.006)\end{array}$ \\
\hline $\ln G D P$ & $\begin{array}{c}9.049 * * * \\
(0.939)\end{array}$ & $\begin{array}{c}6.291 * * * \\
(1.397)\end{array}$ & $\begin{array}{c}-3.292 * * * \\
(1.159)\end{array}$ & $\begin{array}{l}-2.861 \text { * } \\
(1.560)\end{array}$ \\
\hline $\operatorname{lnFDI}$ & $\begin{array}{l}-0.502 \\
(0.434)\end{array}$ & $\begin{array}{l}-0.667 \\
(0.422)\end{array}$ & $\begin{array}{c}1.362^{* * *} \\
(0.448)\end{array}$ & $\begin{array}{l}0.771^{*} \\
(0.442)\end{array}$ \\
\hline InEnergy & $\begin{array}{l}-0.100 \\
(1.751)\end{array}$ & $\begin{array}{c}2.149 \\
(3.249)\end{array}$ & $\begin{array}{l}3.144^{* *} \\
(1.245)\end{array}$ & $\begin{array}{l}7.676^{* *} \\
(3.363)\end{array}$ \\
\hline InUrban & $\begin{array}{c}-8.900^{* * *} \\
(1.533)\end{array}$ & $\begin{array}{c}0.799 \\
(5.690)\end{array}$ & $\begin{array}{c}-1.835^{*} \\
(1.072)\end{array}$ & $\begin{array}{c}-10.582 * \\
(5.896)\end{array}$ \\
\hline Constant & $\begin{array}{l}-18.594 \\
(16.654)\end{array}$ & $\begin{array}{l}-60.676 \\
(38.920)\end{array}$ & $\begin{array}{c}-45.569^{* * *} \\
(13.575)\end{array}$ & $\begin{array}{c}18.215 \\
(40.649)\end{array}$ \\
\hline Observations & 179 & 179 & 179 & 179 \\
\hline$R$-squared & 0.636 & 0.656 & 0.977 & 0.979 \\
\hline Hausman test & - & - & - & - \\
\hline Chi-square (5) (6) & 35.88 & - & 268.93 & - \\
\hline Prob $>$ chi-square & 0.000 & - & 0.000 & - \\
\hline
\end{tabular}

Note: Standard errors are in parentheses; ${ }^{* * *},{ }^{* *}, *$ show significance at the $0.01,0.05$, and 0.1 level, respectively.

\subsection{Green-Field Investment}

Green-field investment is also used as a mediator because green-field projects are riskier for the environment. The Panel A model in Table 5 shows no statistically considerable impact of trade liberalization on green-field investment, as both random and fixed effect models are non-significant. However, as shown in the Panel B model, $\ln$ GFI has a strongly significant adverse effect on the overall environmental performance in random and fixed effects models. This result is interesting, as the results for FDI in the above estimations are not significant, but $\ln G F I$ considerably lessens the EPI score of sample South and East Asian countries. The mediation role of green-field investment with regards to trade liberalization and environmental performance is not established. This result is consistent with the prior findings of Adeel et al. [32].

Table 5. Regression results with Mediator_GFI.

\begin{tabular}{|c|c|c|c|c|}
\hline \multirow{3}{*}{ Variables } & (1) & (2) & (3) & (4) \\
\hline & \multicolumn{2}{|c|}{ Panel_A } & \multicolumn{2}{|c|}{ Panel_B } \\
\hline & Random Effect & Fixed Effect & Random Effect & Fixed Effect \\
\hline $\ln G F I$ & & & $\begin{array}{c}-3.214^{* *} \\
(1.831)\end{array}$ & $\begin{array}{c}-5.581 * * * \\
(1.707)\end{array}$ \\
\hline Trade & $\begin{array}{l}-0.000 \\
(0.001)\end{array}$ & $\begin{array}{l}-0.001 \\
(0.001)\end{array}$ & $\begin{array}{c}-0.059^{* * *} \\
(0.022)\end{array}$ & $\begin{array}{c}-0.137^{* * * *} \\
(0.023)\end{array}$ \\
\hline $\ln G D P$ & $\begin{array}{c}0.009 \\
(0.163)\end{array}$ & $\begin{array}{l}0.535^{* *} \\
(0.260)\end{array}$ & $\begin{array}{c}37.870 * * * \\
(3.858)\end{array}$ & $\begin{array}{c}29.199 * * * \\
(5.728)\end{array}$ \\
\hline
\end{tabular}


Table 5. Cont.

\begin{tabular}{|c|c|c|c|c|}
\hline & (1) & (2) & (3) & (4) \\
\hline \multirow{2}{*}{ Variables } & \multicolumn{2}{|c|}{ Panel_A } & \multicolumn{2}{|c|}{ Panel_B } \\
\hline & Random Effect & Fixed Effect & Random Effect & Fixed Effect \\
\hline \multirow{2}{*}{$\operatorname{lnFDI}$} & $0.295 * * *$ & $0.248 * * *$ & -0.130 & -1.399 \\
\hline & $(0.077)$ & $(0.079)$ & (1.953) & $(1.759)$ \\
\hline \multirow{2}{*}{ InEnergy } & 0.331 & -0.680 & -5.623 & 5.156 \\
\hline & $(0.273)$ & $(0.605)$ & (6.011) & (13.203) \\
\hline \multirow{2}{*}{ InUrban } & 0.122 & -0.287 & $-30.829 * * *$ & 1.730 \\
\hline & $(0.233)$ & $(1.060)$ & (5.018) & $(23.035)$ \\
\hline \multirow{2}{*}{ Constant } & 1.617 & -0.489 & $-121.886^{* *}$ & -255.548 \\
\hline & $(2.708)$ & $(7.251)$ & (61.638) & $(157.526)$ \\
\hline Observations & 179 & 179 & 179 & 179 \\
\hline$R$-squared & 0.181 & 0.214 & 0.639 & 0.678 \\
\hline Hausman test: & - & - & - & - \\
\hline Chi-square (5) (6) & 4.88 & - & 79.10 & - \\
\hline Prob $>$ chi-square & 0.430 & - & 0.000 & - \\
\hline
\end{tabular}

Note: Standard errors are in parentheses; ${ }^{* * *},{ }^{* *}, *$ show significance at the $0.01,0.05$, and 0.1 level, respectively.

\section{Heterogeneous Differences}

The current study includes the dummies based on manufacturing economy, per capita income, and population size to explore the differences among the panel data sample. The panel regression results are shown in Table 6, and columns (1) and (2) indicate that countries with higher per capita income positively influence EPI. This finding is quite satisfactory and implies that earned income, as an outcome of economic growth, is spent on boosting environmental quality. In emerging countries, the initial stage of economic growth emphasizes increasing economic output rather than focusing on environmental quality. Prior studies by Ahmed et al. [41], Ang [42], Lau et al. [94], Lopez-Menendez et al. [95], and Iwata et al. [96] revealed that consistent growth in per capita income helps the regeneration of the environment as countries become more able to opt environment friendly technologies. The explanations lying behind this fact are attributed to factors such as strong institutions, environmental rules and regulations, awareness amongst people regarding the environment, and the efficient utilization of resources [49].

Table 6. Regression results with heterogeneous differences.

\begin{tabular}{|c|c|c|c|c|c|c|}
\hline \multirow{3}{*}{ Variables } & (1) & (2) & (3) & (4) & (5) & (6) \\
\hline & \multicolumn{2}{|c|}{ Per Capita Income } & \multicolumn{2}{|c|}{ Manufacturing GDP } & \multicolumn{2}{|c|}{ Population } \\
\hline & Random Effect & Fixed Effect & Random Effect & Fixed Effect & Random Effect & Fixed Effect \\
\hline Trade & $\begin{array}{c}-0.076^{* * *} \\
(0.023)\end{array}$ & $\begin{array}{c}-0.127 * * * \\
(0.025)\end{array}$ & $\begin{array}{l}-0.022 \\
(0.021)\end{array}$ & $\begin{array}{c}-0.101^{* * *} \\
(0.024)\end{array}$ & $\begin{array}{c}-0.085 * * * \\
(0.023)\end{array}$ & $\begin{array}{c}-0.128 * * * \\
(0.024)\end{array}$ \\
\hline PCI_dummy & $\begin{array}{l}3.296 \text { * } \\
(2.762)\end{array}$ & $\begin{array}{c}2.960 \\
(2.949)\end{array}$ & - & - & r & - \\
\hline $\ln G D P$ & $\begin{array}{c}37.886^{* * *} \\
(3.874)\end{array}$ & $\begin{array}{c}26.889 * * * \\
(5.861)\end{array}$ & $\begin{array}{c}37.462 * * * \\
(3.957)\end{array}$ & $\begin{array}{c}30.015^{* * *} \\
(5.595)\end{array}$ & $\begin{array}{c}37.879 * * * \\
(3.901)\end{array}$ & $\begin{array}{c}26.310 * * * \\
(5.817)\end{array}$ \\
\hline Mfg.GDP_dummy & - & - & $\begin{array}{l}-2.031 * \\
(1.848)\end{array}$ & $\begin{array}{c}-10.055^{* * *} \\
(2.318)\end{array}$ & - & - \\
\hline $\ln F D I$ & $\begin{array}{l}-1.878 \\
(1.835)\end{array}$ & $\begin{array}{c}-2.999 * \\
(1.771)\end{array}$ & $\begin{array}{l}-0.687 \\
(2.019)\end{array}$ & $\begin{array}{c}-3.737^{* *} \\
(1.683)\end{array}$ & $\begin{array}{l}-1.947 \\
(1.844)\end{array}$ & $\begin{array}{c}-3.012 \\
(1.768)\end{array}$ \\
\hline InEnergy & $\begin{array}{l}-5.079 \\
(6.957)\end{array}$ & $\begin{array}{c}10.168 \\
(13.593)\end{array}$ & $\begin{array}{c}-10.774 \text { ** } \\
(5.355)\end{array}$ & $\begin{array}{l}-10.265 \\
(13.593)\end{array}$ & $\begin{array}{l}-1.679 \\
(7.024)\end{array}$ & $\begin{array}{c}7.818 \\
(13.564)\end{array}$ \\
\hline InUrban & $\begin{array}{c}-32.135^{* * *} \\
(6.263)\end{array}$ & $\begin{array}{c}-2.296 \\
(24.362)\end{array}$ & $\begin{array}{c}-25.644^{* * *} \\
(4.188)\end{array}$ & $\begin{array}{c}16.318 \\
(22.701)\end{array}$ & $\begin{array}{c}-36.561 * * * \\
(6.524)\end{array}$ & $\begin{array}{c}4.844 \\
(23.724)\end{array}$ \\
\hline Population_dummy & (100 & 1 & 1 & (1 & $\begin{array}{c}-0.915 \text { * } \\
(3.201)\end{array}$ & $\begin{array}{l}-3.901 \\
(3.431)\end{array}$ \\
\hline Constant & $\begin{array}{c}-117.666 * \\
68.174\end{array}$ & $\begin{array}{l}-218.634 \\
(165.700)\end{array}$ & $\begin{array}{c}-166.642 \text { *** } \\
(58.470)\end{array}$ & $\begin{array}{c}-378.289 * * \\
(156.615)\end{array}$ & $\begin{array}{l}-84.439 \\
(69.165)\end{array}$ & $\begin{array}{l}-266.021 \\
(162.438)\end{array}$ \\
\hline Observations & 179 & 179 & 179 & 179 & 179 & 179 \\
\hline$R$-squared & 0.637 & 0.659 & 0.612 & 0.692 & 0.634 & 0.659 \\
\hline Hausman test: & - & - & - & - & - & - \\
\hline Chi-square (6) & 234.85 & - & 288.50 & - & 59.10 & - \\
\hline Prob $>$ chi-square & 0.000 & - & 0.000 & - & 0.000 & - \\
\hline
\end{tabular}


In the context of $M f g . G D P \_d u m m y$, the result is negative and statistically significant, as shown in columns (3) and (4) of Table 6. It is found that countries having higher manufacturing GDP reduce their EPI score by 2.031 percent in the case of the random effects model and 10.055 percent in the case of fixed effects estimation. It has been witnessed that economic growth and development come from good performance of the manufacturing sector, but it occurs at the expense of environmental degradation. The manufacturing sector relies more on fossil fuels in developing countries to meet energy needs, which is the key factor of economic activity and a prime cause of pollutant emissions. Ali et al. [97] and Doytch and Narayan [98] also argued that a higher manufacturing share of the GDP negatively impacts a country's environmental performance.

Moving towards population growth, which is the main reason for elucidating the environment quality dynamics [99], it is argued that human activities due to increased population rate constitute a significant portion of pollutants in the form of $\mathrm{NO}_{2}, \mathrm{CO}_{2}$, and $\mathrm{SO}_{2}$, through the combustion of fossil fuels, and so on. The concentration of pollutants in the atmosphere increased as a consequence of such anthropogenic activities. Table 6 columns (5) and (6) show that the Population_dummy result was not significant. However, previous studies of Nasir and Ur-Rehman [45] and Alvarado et al. [100] have pointed out that population growth exacerbates emissions and worsens environment quality, as it is linked with the use of fossil fuels energy, urbanization, massive transportation, deforestation, and so on.

\section{Conclusions}

Debates over the merits of trade liberalization have been going on for some time. Still, over the last decade, the issue has intensified as environmentalists and economists have squared off over the environmental consequences of trade openness. It is argued that trade contributes majorly to the economic growth and development of a country. On the one hand, it generates wealth by providing employment opportunities; while on the other hand, it leads to environmental deterioration. The earlier studies have reported mixed results regarding trade liberalization and the environment. To the authors' knowledge, previous studies have generally assessed the causal association of trade and $\mathrm{CO}_{2}$ emissions, but they have not considered a comprehensive proxy to measure the environment, (i.e., EPI). This study investigated trade liberalization and EPI in developing Asian countries from 2002 to 2016 based on available data; the conventional methods for panel data (i.e., random effects and fixed effects) were employed. Unlike previous studies, mediation and difference analyses were performed to investigate the systematic effect of trade liberalization.

The empirical findings indicate that the environmental quality measured by EPI score slumps as more trade liberalization occurs. It suggests that in developing countries, trade liberalization has more hazardous environmental effects. It may suggest that trade liberalization boosts energy consumption and potentially causes the deterioration of the environment. However, GDP has a beneficial effect on environmental performance as the countries are more inclined to invest in energy-efficient technologies. Economic growth and increase in per capita income amplify the likelihood of people to claim an unpolluted environment. There is no doubt that FDI is a principal factor for economic development. Still, developing countries should focus more on clean investment and technology transfer, as the results are found to be insignificant. Urbanization was also found to be adversely related to EPI. Moreover, mediation analysis and group differences were also conducted to address the endogeneity and cross-sectional differences. The mediation analysis showed that trade and EPI are partially influenced by climate change; while in the case of greenfield investment the results are not found to be significant. In group analysis, the findings showed that countries having higher per capita income improve environmental performance. On the contrary, countries having higher manufacturing industries and population growth lessens the environmental performance.

However, the emerging countries of Asia are moving towards an eco-friendly-based domestic production process, yet the international trade in such countries is not focused 
on environmentally friendly goods. The key policy upshot from the outcomes is that developing countries must not only focus on implementing the strategies needed for trade liberalization but also focus on environmental reforms to decrease the worst environmental effects of climate change. Countries should emphasize the quality of exports instead of just the quantity. The conclusion suggests that these emerging countries of South and East Asia should put forth an inclusive strategy to negotiate and collaborate on green trade by diminishing bad energy and emission-intensive imports and improving climate change performance measures. A general method to lessen environmental pollution and climate change is through emphasizing green domestic consumption. Our empirical outcomes also specify that South and East Asian emerging countries should emphasize substituting energy-efficient production processes for trade and domestic products. It is necessary to stress the dual role of reducing the adverse externalities deriving from trade liberalization. The other issues, such as urbanization, industrial development, overcrowding, and exploiting the positive externalities such as public provisioning of waste management, eco-friendly infrastructure, and transportation systems, also need to be improved. The policy implications discussed here are aligned with the prior studies $[21,27,32,38-40,67,81]$.

Moreover, the emerging developing nations should speed up the shift from fossil fuels to less polluting alternative energy sources to reduce carbon and other emissions locally and globally. Use of energy from fossil fuels is an important channel for trade and FDI's negative impact on the environment. According to the IPCC, renewable energy such as solar, wind, and hydropower can be very beneficial to reduce the pollution levels in Asia. The sustainable and healthy use of natural resources is very important for the betterment of future generations. The findings emphasize the need to have effective and improved methods of energy production and distribution. The governments of South and East Asian countries should allocate more budgets for research and development to plan environmentally friendly trade policies. More investment, training, transparency, education, and collaboration are required to reduce the negative effects of trade on the environment. There are also some limitations, which future studies could consider with regards to examining environmental performance. Our dataset consists of a sample from selected Asian countries; however, future studies could work on large sample for more generalized findings. In addition, advanced econometric techniques can help to further explore the heterogeneous differences among countries. Overall, the results of this study are helpful to understand the trade-environment nexus in emerging countries.

Author Contributions: All authors contributed equally to the manuscript. A.R. conceptualized and wrote the original manuscript. H.S. and K.J. supervised the study and helped in empirical analysis. W.Ż.S. and P.S. wrote the review and edited the manuscript. All authors have read and agreed to the published version of the manuscript.

Funding: This research was supported by the National Natural Science Foundation of China (General Project, 71873077), Humanities and Social Science Research Foundation of Education Ministry of China (19YJA790074), and Social Science Foundation of Shandong province (19BJCJ36).

Institutional Review Board Statement: Not applicable.

Informed Consent Statement: Not applicable.

Data Availability Statement: The data will be available on request.

Conflicts of Interest: The authors declare no conflict of interest.

\section{References}

1. Dong, K.; Sun, R.; Dong, X. $\mathrm{CO}_{2}$ emissions, natural gas and renewables, economic growth: Assessing the evidence from China. Sci. Total Environ. 2018, 640, 293-302. [CrossRef] [PubMed]

2. Destek, M.A.; Sarkodie, S.A. Investigation of environmental Kuznets curve for ecological footprint: The role of energy and financial development. Sci. Total Environ. 2019, 650, 2483-2489. [CrossRef]

3. Bekun, F.V.; Emir, F.; Sarkodie, S.A. Another look at the relationship between energy consumption, carbon dioxide emissions, and economic growth in South Africa. Sci. Total Environ. 2019, 655, 759-765. [CrossRef] [PubMed] 
4. IPCC. AR5 Climate Change 2014: Impacts, Adaptation, and Vulnerability; Cambridge University Press: Cambridge, UK, 2014; Available online: https://www.ipcc.ch/site/assets/uploads/2018/02/WGIIAR5-PartB_FINAL.pdf (accessed on 12 April 2021).

5. World Economic Forum. In 2020 Asia will have the world's largest GDP. Here's what that means. Available online: https: //www.weforum.org/agenda/2019/12/asia-economic-growth/ (accessed on 4 April 2021).

6. ADB. The Economics of Climate Change in Southeast Asia: A Regional Review. Asian Development Bank (ADB). Available online: https://www.adb.org/publications/economics-climate-change-southeast-asia-regional-review (accessed on 4 April 2021).

7. ADB. Environmental, Social, and Governance Investment: Opportunities and Risks for Asia. Available online: https://www.adb. org/publications/environmental-social-governance-investment-opportunities-risks-asia (accessed on 2 April 2021).

8. Rohde, R.A.; Muller, R.A. Air pollution in China: Mapping of concentrations and sources. PLoS ONE 2015, 10, 1-15. [CrossRef]

9. British Petroleum. Statistical Review of World Energy. Available online: https://www.bp.com/en/global/corporate/energyeconomics/statistical-review-of-world-energy.html (accessed on 28 March 2021).

10. UNEP. Annual Report 2018. Available online: https://www.unenvironment.org/annualreport/2018/index.php\#cover (accessed on 28 March 2021).

11. Gozgor, G.; Can, M. Export product diversification and the environmental Kuznets curve: Evidence from Turkey. Environ. Sci. Pollut. Res. 2016, 23, 21594-21603. [CrossRef]

12. Liu, B.; Wang, D.; Xu, Y.; Liu, C.; Luther, M. A multi-regional input-output analysis of energy embodied in international trade of construction goods and services. J. Clean. Prod. 2018, 201, 439-451. [CrossRef]

13. Nathaniel, S.; Khan, S.A.R. The nexus between urbanization, renewable energy, trade, and ecological footprint in ASEAN countries. J. Clean. Prod. 2020, 272, 122709. [CrossRef]

14. Grossman, G.M.; Krueger, A.B. Environmental Impacts of a North American Free Trade Agreement; National Bureau of Economic Research: Cambridge, MA, USA, 1991; p. 3914.

15. Shafik, N. Economic development and environmental quality: An econometric analysis. Oxf. Econ. Pap. 1994, 46, 757-773. [CrossRef]

16. Khan, Z.A.; Koondhar, M.A.; Aziz, N.; Ali, U.; Tianjun, L. Revisiting the effects of relevant factors on Pakistan's agricultural products export. Agric. Econ. 2020, 66, 527-541.

17. Abdouli, M.; Hammami, S. The dynamic links between environmental quality, foreign direct investment, and economic growth in the Middle Eastern and North African Countries (MENA Region). J. Knowl. Econ. 2016, 9, 833-853. [CrossRef]

18. Wacziarg, R.; Welch, K.H. Trade liberalization and growth: New evidence. World Bank Econ. Rev. 2008, 22, 187-231. [CrossRef]

19. Grether, J.; DeMelo, J. Globalization and Dirty Industries: Do Pollution Havens Matter? National Bureau of Economic Research: Cambridge, MA, USA, 2003; p. 9776.

20. Antweiler, W.; Copeland, B.R.; Taylor, S. Is free trade good for the environment? Am. Econ. Rev. 2001, 91, 877-908. [CrossRef]

21. Ashraf, A.; Doytch, N.; Uctum, M. Foreign direct investment and the environment: Disentangling the impact of green field investment and merger and acquisition sales. Sustain. Account. Manag. Policy J. 2020, 12, 51-73. [CrossRef]

22. EEA. Climate Change, Impacts and Vulnerability in Europe 2012. Available online: https://ec.europa.eu/clima/policies/ adaptation/how/challenges_en\#tab-0-1 (accessed on 15 April 2021).

23. Selden, T.; Song, D. Environmental quality and development: Is these a Kuznets Curve for air pollution emissions. J. Environ. Econ. Manag. 1994, 27, 147-162. [CrossRef]

24. Janke, K.; Propper, C.; Henderson, J. Do current levels of air pollution kill? The impact of air pollution on population mortality in England. Health Econ. 2009, 18, 1031-1055. [CrossRef]

25. Zhang, X.; Shi, M.; Li, Y.; Pang, R.; Xiang, N. Correlating PM 2.5 concentrations with air pollutant emissions: A longitudinal study of the Beijing-Tianjin-Hebei region. J. Clean. Prod. 2018, 179, 103-113. [CrossRef]

26. Ouyang, X.; Shao, Q.; Zhu, X.; He, Q.; Xiang, C.; Wei, G. Environmental regulation, economic growth and air pollution: Panel threshold analysis for OECD countries. Sci. Total Environ. 2019, 657, 234-241. [CrossRef]

27. Dogan, E.; Seker, F. The influence of real output, renewable and non-renewable energy, trade and financial development on carbon emissions in the top renewable energy countries. Renew. Sustain. Energy Rev. 2016, 60, 1074-1085. [CrossRef]

28. Kim, D.H.; Suen, Y.B.; Lin, S.C. Carbon dioxide emissions and trade: Evidence from disaggregate trade data. Energy Econ. 2019, 78, 13-28. [CrossRef]

29. Ikram, M.; Zhang, Q.; Sroufe, R.; Shah, Z. Towards a sustainable environment: The nexus between ISO 14001, renewable energy consumption, access to electricity, agriculture and $\mathrm{CO}_{2}$ emissions in SAARC countries. Sustain. Prod. Consump. 2020, 22, 218-230. [CrossRef]

30. Mendonca, A.K.S.; Barni, G.A.C.; Moro, M.F.; Bornia, A.C.; Kupek, E.; Fernandes, L. Hierarchical modeling of the 50 largest economies to verify the impact of GDP, population and renewable energy generation in $\mathrm{CO}_{2}$ emissions. Sustain. Prod. Consump. 2020, 22, 58-67. [CrossRef]

31. Dick, C.; Jorgenson, A.K. Sectoral foreign investment and nitrous oxide emissions: A quantitative investigation. Soc. Nat. Resour. 2010, 23, 71-82. [CrossRef]

32. Adeel, R.M.; Abu-Bakar, N.A.; Olajide-Raji, J. Green-field investment and environmental performance: A case of selected nine developing countries of Asia. Environ. Prog. Sustain. Energy 2017, 37, 1085-1092. [CrossRef]

33. Ozturk, I.; Al-Mulali, U.; Saboori, B. Investigating the environmental Kuznets curve hypothesis: The role of tourism and ecological footprint. Environ. Sci. Pollut. Res. 2016, 23, 1916-1928. [CrossRef] 
34. Shahbaz, M.; Nasreen, S.; Ahmed, K.; Hammoudeh, S. Trade openness-carbon emissions nexus: The importance of turning points of trade openness for country panels. Energy Econ. 2017, 61, 221-232. [CrossRef]

35. Sebri, M.; Ben-Salha, O. On the causal dynamics between economic growth, renewable energy consumption, $\mathrm{CO}_{2}$ emissions and trade openness: Fresh evidence from BRICS countries. Renew. Sustain. Energy Rev. 2014, 39, 14-23. [CrossRef]

36. Cole, M.A.; Elliott, R.J.R. Do Environmental Regulations Influence Trade Patterns? Testing Old and New Trade Theories. World Econ. 2003, 26, 1163-1186. [CrossRef]

37. Udeagha, M.C.; Ngepah, N. Revisiting trade and environment nexus in South Africa: Fresh evidence from new measure. Environ. Sci. Pollut. Res. 2019, 26, 29283-29306.

38. Omri, A.; Daly, S.; Rault, C.; Chaibi, A. Financial development, environmental quality, trade and economic growth: What causes what in MENA countries. Energy Econ. 2015, 48, 242-252.

39. Aller, C.; Ductor, L.; Herrerias, M.J. The world trade network and the environment. Energy Econ. 2015, 52, 55-68. [CrossRef]

40. Mahrinasari, M.S.; Haseeb, M.; Ammar, J.; Meiryani. Is Trade Liberalization A Hazard to Sustainable Environment? Fresh Insight from Asean Countries. Pol. J. Manag. Stud. 2019, 19, 249-259.

41. Ahmed, A.; Uddin, G.S.; Sohag, K. Biomass energy, technological progress and the environmental Kuznets curve: Evidence from selected European countries. Biomass Bioenergy 2016, 90, 202-208. [CrossRef]

42. Ang, J.B. $\mathrm{CO}_{2}$ emissions, energy consumption, and output in France. Energy Policy 2007, 35, 4772-4778. [CrossRef]

43. Apergis, N.; Payne, J.E. Energy consumption and growth in South America: Evidence from a panel error correction model. Energy Econ. 2010, 32, 1421-1426. [CrossRef]

44. Acaravci, A.; Ozturk, I. On the relationship between energy consumption, $\mathrm{CO}_{2}$ emissions and economic growth in Europe. Energy 2010, 35, 5412-5420. [CrossRef]

45. Nasir, M.; Ur-Rehman, F. Environmental Kuznets Curve for carbon emissions in Pakistan: An empirical investigation. Energy Policy 2011, 39, 1857-1864. [CrossRef]

46. Jayanthakumaran, K.; Verma, R.; Liu, Y. $\mathrm{CO}_{2}$ emissions, energy consumption, trade and income: A comparative analysis of China and India. Energy Policy 2012, 42, 450-460. [CrossRef]

47. Shahbaz, M.; Hye, Q.M.A.; Tiwari, A.K.; Leitao, N.C. Economic growth, energy consumption, financial development, international trade and $\mathrm{CO}_{2}$ emissions in Indonesia. Renew. Sustain. Energy Rev. 2013, 25, 109-121.

48. Kasman, A.; Duman, Y.S. $\mathrm{CO}_{2}$ emissions, economic growth, energy consumption, trade and urbanization in new EU member and candidate countries: A panel data analysis. Econ. Mod. 2015, 44, 97-103. [CrossRef]

49. Dogan, E.; Turkekul, B. $\mathrm{CO}_{2}$ emissions, real output, energy consumption, trade, urbanization and financial development: Testing the EKC hypothesis for the USA. Environ Sci. Pollut. Res. 2016, 23, 1203-1213. [CrossRef]

50. Kwakwa, P.A.; Alhassan, H.; Adu, G. Effect of Natural Resources Extraction on Energy Consumption and Carbon Dioxide Emission in Ghana; Munich Personal RePEc Archive: Munich, Germany, 2018; p. 85401.

51. Hasson, A.; Masih, M. Energy Consumption, Trade Openness, Economic Growth, Carbon Dioxide Emissions and Electricity Consumption: Evidence from South Africa Based on ARDL; Munich Personal RePEc Archive: Munich, Germany, 2017; p. 79424.

52. Roy, J. On the environmental consequences of intra-industry trade. J. Environ. Econ. Manag. 2017, 83, 50-67. [CrossRef]

53. Zerbo, E. Income-environment relationship in Sub-Saharan African countries: Further evidence with trade openness. Environ. Sci. Pollut. Res. 2017, 24, 16488-16502. [CrossRef]

54. Destek, M.A.; Balli, E.; Manga, M. The relationship between $\mathrm{CO}_{2}$ emission, energy consumption, urbanization and trade openness for selected CEECs. Res. World Econ. 2016, 7, 52. [CrossRef]

55. Jabeen, A. Is trade liberalization, economic growth, energy consumption good for the environment? Rom. J. Fisc. Policy 2015, 6, $1-13$.

56. Ling, C.H.; Ahmed, K.; Muhamad, R.B.; Shahbaz, M. Decomposing the trade-environment nexus for Malaysia: What do the technique, scale, composition, and comparative advantage effect indicate? Environ. Sci. Pollut. Res. 2015, 22, 20131-20142. [CrossRef]

57. Aichele, R.; Felbermayr, G. The effect of the Kyoto protocol on carbon emissions. J. Policy Anal. Manag. 2013, 32, 731-757. [CrossRef]

58. Frankel, J.A.; Rose, A.K. Is trade good or bad for the environment? Sorting out the causality. Rev. Econ. Stat. 2005, 87, 85-91. [CrossRef]

59. Zhang, S.; Liu, X.; Bae, J. Does trade openness affect $\mathrm{CO}_{2}$ emissions: Evidence from ten newly industrialized countries? Environ. Sci. Pollut. Res. 2017, 24, 17616-17625. [CrossRef]

60. Li, Z.; Xu, N.; Yuan, J. New evidence on trade-environment linkage via air visibility. Econ. Lett. 2015, 128, 72-74. [CrossRef]

61. Baek, J.; Cho, Y.; Koo, W.W. The Environmental Consequences of Globalization: A Country-specific Time-series Analysis. Ecol. Econ. 2009, 68, 2255-2264. [CrossRef]

62. Wiebe, K.S.; Bruckner, M.; Giljum, S.; Lutz, C.; Polzin, C. Carbon and Materials Embodied in the International Trade of Emerging Economies. J. Ind. Ecol. 2012, 16, 636-646. [CrossRef]

63. Mudakkar, S.R.; Zaman, K.; Shakir, H.; Arif, M.; Naseen, I.; Naz, L. Determinants of energy consumption function in SAARC countries: Balancing the odds. Renew. Sust. Energ. Rev. 2013, 28, 566-574. [CrossRef]

64. Liu, Q.; Wang, S.; Zhang, W.; Zhan, D.; Li, J. Does foreign direct investment affect environmental pollution in China's cities? A spatial econometric perspective. Sci. Total Environ. 2018, 613, 521-529. [CrossRef] 
65. Bildirici, M.; Gokmenoglu, S.M. The impact of terrorism and FDI on environmental pollution: Evidence from Afghanistan, Iraq, Nigeria, Pakistan, Philippines, Syria, Somalia, Thailand and Yemen. Environ. Impact Assess. Rev. 2020, 81, 106340. [CrossRef]

66. Demena, B.A.; Afesorgbor, S.K. The effect of FDI on environmental emissions: Evidence from a meta-analysis. Energy Policy 2020, 138, 111192. [CrossRef]

67. Alhassan, A.; Usman, O.; Ike, G.N.; Sarkodie, S.A. Impact assessment of trade on environmental performance: Accounting for the role of government integrity and economic development in 79 countries. Heliyon 2020, 6, e05046. [CrossRef]

68. World Bank. Energy Use Data. Available online: https://data.worldbank.org/indicator/EG.USE.PCAP.KG.OE (accessed on 4 April 2021).

69. Huaman, R.N.E.; Jun, T.X. Energy related $\mathrm{CO}_{2}$ emissions and the progress on CCS projects: A review. Renew. Sustain. Energy Rev. 2014, 31, 368-385. [CrossRef]

70. Bernard, J.; Mandal, S.K. The impact of trade openness on environmental quality: An empirical analysis of emerging and developing economies. In WIT Transactions on Ecology and the Environment; WIT Press: Southampton, UK, 2016 ; pp. $1743-3541$.

71. Jamel, L.; Maktouf, S. The nexus between economic growth, financial development, trade openness, and $\mathrm{CO}_{2}$ emissions in European countries. Cogent. Econ. Financ. 2017, 5, 1341456. [CrossRef]

72. Essandoh, O.K.; Islam, M.; Kakinaka, M. Linking international trade and foreign direct investment to $\mathrm{CO}_{2}$ emissions: Any differences between developed and developing countries? Sci. Total. Environ. 2020, 712, 136437. [CrossRef] [PubMed]

73. Kohler, $\mathrm{M} . \mathrm{CO}_{2}$ emissions, energy consumption, income and foreign trade: A South African perspective. Energy Policy 2013, 63, 1042-1050. [CrossRef]

74. Raza, S.A.; Shah, N. Impact of Financial Development, Economic Growth and Energy Consumption on Environmental Degradation: Evidence from Pakistan; Munich Personal RePEc Archive: Munich, Germany, 2018; p. 87095.

75. Solarin, S.A.; Al-Mulali, U. Influence of foreign direct investment on indicators of environmental degradation. Environ. Sci. Pollut. Res. 2018, 25, 24845-24859. [CrossRef]

76. Fernández-Amador, O.; Francois, J.F.; Oberdabernig, D.A.; Tomberger, P. Carbon Dioxide Emissions and Economic Growth: An Assessment Based on Production and Consumption Emission Inventories. Ecol. Econ. 2017, 135, 269-279. [CrossRef]

77. Balin, B.E.; Akan, H.D.M.; Altayligil, Y.B. Trade liberalization and environmental degradation: A time series analysis for Turkey. In Proceedings of the 19th Annual Conference of ETSG, Florence, Italy, 14-16 September 2017.

78. Ozturk, I.; Acaravci, A. The long-run and causal analysis of energy, growth, openness and financial development on carbon emissions in Turkey. Energy Econ. 2013, 36, 262-267. [CrossRef]

79. Wan, R.; Nakada, M.; Takarada, Y. Trade liberalization in environmental goods. Resour. Energy Econ. 2018, 51, 44-66. [CrossRef]

80. Cherniwchan, J. Trade liberalization and the environment: Evidence from NAFTA and US manufacturing. J. Int. Econ. 2017, 105, 130-149. [CrossRef]

81. Aziz, N.; Sharif, A.; Raza, A.; Rong, K. Revisiting the role of forestry, agriculture, and renewable energy in testing environment Kuznets curve in Pakistan: Evidence from Quantile ARDL approach. Environ. Sci. Pollut. Res. 2020, 27, 10115-10128. [CrossRef]

82. Si, R.; Aziz, N.; Raza, A. Short and long-run causal effects of agriculture, forestry, and other land use on greenhouse gas emissions: Evidence from China using VECM approach. Environ. Sci. Pollut. Res. 2021, 1-12. [CrossRef]

83. Si, R.; Aziz, N.; Liu, M.; Lu, Q. Natural disaster shock, risk aversion and corn farmers' adoption of degradable mulch film: Evidence from Zhangye, China. Int. J. Clim. Chang. Strateg. Manag. 2021, 13, 60-77. [CrossRef]

84. Koondhar, M.A.; Aziz, N.; Tan, Z.; Yang, S.; Abbasi, K.R.; Kong, R. Green growth of cereal food production under the constraints of agricultural carbon emissions: A new insights from ARDL and VECM models. Sustain. Energy Technol. Assess 2021, $47,101452$.

85. Aziz, N.; Sharif, A.; Raza, A.; Jermsittiparsert, K. The role of natural resources, globalization, and renewable energy in testing the EKC hypothesis in MINT countries: New evidence from Method of Moments Quantile Regression approach. Environ. Sci. Pollut. Res. 2021, 28, 13454-13468. [CrossRef]

86. Aziz, N.; Mihardjo, L.W.; Sharif, A.; Jermsittiparsert, K. The role of tourism and renewable energy in testing the environmental Kuznets curve in the BRICS countries: Fresh evidence from methods of momentsquantile regression. Environ. Sci. Pollut. Res. 2020, 27, 39427-39441. [CrossRef]

87. Xie, Q.; Wang, X.; Cong, X. How does foreign direct investment affect $\mathrm{CO}_{2}$ emissions in emerging countries? New findings from a nonlinear panel analysis. J. Clean. Prod. 2020, 249, 119422. [CrossRef]

88. Shahbaz, M.; Nasreen, S.; Abbas, F.; Anis, O. Does foreign direct investment impede environmental quality in high-, middle-, and low-income countries? Energy Econ. 2015, 51, 275-287. [CrossRef]

89. Khan, A.; Hussain, J.; Bano, S.; Chenggang, Y. The repercussions of foreign direct investment, renewable energy, and health expenditure on environmental decay? An econometric analysis of B\&RI countries. J. Environ. Plan. Manag. 2020, 63, $1965-1986$.

90. Tamazian, A.; Rao, B.B. Do economic, financial and institutional developments matter for environmental degradation? Evidence from transitional economies. Energy Econ. 2010, 32, 137-145. [CrossRef]

91. Hossain, M.S. Panel estimation for $\mathrm{CO}_{2}$ emissions, energy consumption, economic growth, trade openness and urbanization of newly industrialized countries. Energy Policy 2011, 39, 6991-6999. [CrossRef]

92. Omri, A. $\mathrm{CO}_{2}$ emissions, energy consumption and economic growth nexus in MENA countries: Evidence from simultaneous equations models. Energy Econ. 2013, 40, 657-664. [CrossRef]

93. Roodman, D. How to do Xtabond2: An Introduction to Difference and System GMM in Stata. Stata J. Promot. Commun. Stat. Stata 2009, 9, 86-136. [CrossRef] 
94. Lau, L.S.; Choong, C.K.; Eng, Y.K. Carbon dioxide emission, institutional quality, and economic growth: Empirical evidence in Malaysia. Renew. Energy 2014, 68, 276-281. [CrossRef]

95. Lopez-Menéndez, A.J.; Pérez, R.; Moreno, B. Environmental costs and renewable energy: Re-visiting the environmental Kuznets curve. J. Environ.Manag. 2014, 145, 368-373. [CrossRef]

96. Iwata, H.; Okada, K.; Samreth, S. Empirical study on the environmental Kuznets curve for $\mathrm{CO}_{2}$ in France: The role of nuclear energy. Energy Policy 2010, 38, 4057-4063. [CrossRef]

97. Ali, H.S.; Law, S.H.; Zannah, T.I. Dynamic impact of urbanization, economic growth, energy consumption, and trade openness on $\mathrm{CO}_{2}$ emissions in Nigeria. Environ. Sci. C Pollut. Res. 2016, 23, 12435-12443. [CrossRef]

98. Doytch, N.; Narayan, S. Does FDI influence renewable energy consumption? An analysis of sectoral FDI impact on renewable and non-renewable industrial energy consumption. Energy Econ. 2016, 54, 291-301. [CrossRef]

99. Bongaarts, J. Population growth and global warming. Popul. Dev. Rev. 1992, 18, 299-319. [CrossRef]

100. Alvarado, R.; Ponce, P.; Criollo, A. Environmental degradation and real per capita output: New evidence at the global level grouping countries by income levels. J. Clean. Prod. 2018, 189, 13-20. [CrossRef] 